\title{
Advances in the study of the spider fauna (Aranei) of Russia and adjacent regions: a 2017 update
}

\begin{abstract}
K.G. Mikhailov
Zoological Museum, Moscow Lomonosov State University, Bolshaya Nikitskaya str., 2, Moscow, 125009 Russia.E-mail: mikhailov2000@gmail.com

ABSTRACT: Recent (2017) calculations of spider species richness in the boundaries of Russia and other former Soviet Union republics, as well as between physiographical regions of these territories, are provided in comparison with earlier data. By December 31st, 2017 , 3437 and 2445 spider species were reported from the FSU territories and Russia, respectively. A prediction for a spider species richness of the FSU and Russia is given. 39 spider species lists of both the post-Soviet republics and physiographical regions are provided as electronic supplementary data.

How to cite this paper: Mikhailov K.G. 2021. Advances in the study of the spider fauna (Aranei) of Russia and adjacent regions: a 2017 update // Invert. Zool. Vol.18. No.1. P.2535, Supplements 1.01-1.15, 2.01-2.24. doi: 10.15298/invertzool.18.1.03
\end{abstract}

KEY WORDS: Araneae, diversity, spiders, post-Soviet republics, physiographical regions, fauna, catalogue.

\section{Итоги изучения фауны пауков (Aranei) России и прилежащих стран: обновление 2017 года}

\section{К.Г. Михайлов}

Зоологический музей, Московский гоударственный университет им. М.В. Ломоносова, ул. Большая Никитская, д.2, Москва, 125009 Россия. E-mail: mikhailov2000@gmail.com

РЕЗЮМЕ: Приведены подсчеты разнообразия пауков России и других стран бывшего СССР, а также их физико-географических регионов по состоянию на 2017 год, в сравнении с ранними данными. На 31 декабря 2017 года отмечено 3437 и 2445 видов пауков для территории бывшего СССР и России, соответственно. Дан прогноз видового богатства пауков бывшего СССР и России. В качестве дополнительных электронных приложений дано 39 списков видов пауков пост-советских республик и их физико-географических регионов.

Как цитировать эту статью: Mikhailov K.G. 2021. Advances in the study of the spider fauna (Aranei) of Russia and adjacent regions: a 2017 update // Invert. Zool. Vol.18. No.1. P.25-35, Supplements 1.01-1.15, 2.01-2.24. doi: 10.15298/invertzool.18.1.03

КЛЮЧЕВЫЕ СЛОВА: Araneae, разнообразие, пауки, пост-советские республики, физико-географические регионы, фауна, каталог. 


\section{Introduction}

This paper, being the result of long-term research, contributes to global biodiversity studies. The spider fauna of the USSR territory (in the borders before 1939) was reviewed in detail by D.E. Kharitonov (Charitonov, 1932; Kharitonov, 1936) in his annotated catalogue of spiders covering 1,068 species with 38 subspecies and varieties from 29 families in the basic 1932 version. The work on cataloguing the USSR spider fauna was revived only in 1981 in the framework of a comprehensive study of animal and plant diversity undertaken by the Academy of Sciences of the former USSR. The aim of the entire project is to compile and critically assess all available literature, both taxonomic and faunistic, sources on spiders of Russia and other republics of the former Soviet Union (= FSU) since the 18th century. Compared to World Spider Catalog (WSC, 2020) and its earlier versions (Roewer, 1942, 1954a,b; Platnick, 2014 , etc.), faunistic papers on spiders have not been reviewed worldwide since 1939 (Bonnet, 1955-1959). Separate annotated spider catalogues are compiled for most European and some Asian countries, but not for the FSU countries, the latter despite a considerable number of sources, mostly in Russian, being available. Only local catalogues and checklists, mostly outdated, are available for Estonia (Vilbaste, 1987), Turkmenistan (Mikhailov, Fet, 1994), the Urals (Esyunin, Efimik, 1996), Georgia (Mkheidze, 1997), Tuva Republic (Marusik et al., 2000), Middle Povolzhye (Krasnobaev, 2004), Left-Bank Ukraine (Polchaninova, Prokopenko, 2013, 2017), the Crimea (Kovblyuk, Kastrygina, 2015), etc. Separate works are devoted to the linyphiids (Eskov, 1994) and the salticids (Logunov, Marusik, 2000) of the FSU Asian part, including Mongolia, as well as to the gnaphosid genus Micaria Westring, 1851 (Mikhailov, 1987) and the sac spider genus Clubiona Latreille, 1804 (Mikhailov, 1992b, 2003) of the FSU territory and the salticid genus Yllenus Simon, 1868 of whole Eurasia (Logunov, Marusik, 2003). At present, publication of all available data is impossible because of a too large amount of information that is likely to run to several volumes of a printed text. To date, only a checklist of the spiders of the former USSR together with a bibliographical index covering all literature sources has been published by Mikhailov (1997), followed in 19982000 by several addenda and the second, advanced edition of the checklist without a bibliographical index (Mikhailov, 2013b).

\section{Methods}

This paper aims at providing the latest calculations (as of December 31st, 2017) of spider species diversity of the FSU territories in order to demonstrate changes in the current knowledge. Earlier calculations were published in a number of papers (Mikhailov, 1992a, 1997, 2002, 2012b, 2013a, 2016, etc). An updated and the most complete bibliographical list appeared separately (Mikhailov, 2012a, 2019), with more than 4,220 references. An unpublished list of 2016-2017 literature sources includes 230 references. To avoid re-counting the number of species with changing state borders, the boundaries of the post-Soviet countries are accepted here as of 1992.

Only the published literature data on spider records are used in this project. More than 4,450 sources were entered to the basic card catalogue. A lot of data are scattered in local university books and transactions, collective papers, as well as conference proceedings; such a search needs special efforts in visiting various libraries and contacting numerous colleagues. Among the well-known specialized scientific periodicals, most of the contributions to Russian/Soviet arachnology were published in "Zoologichesky Zhurnal" (before 1992), followed since 1992 by "Arthropoda Selecta". Over the last decade, numerous data appeared also in "Zootaxa" and "ZooKeys".

The scope of spider families follows WSC (2021), with several exceptions (see below and in supplementary materials).

\section{Results and Discussion}

A new, updated version of the checklist is compiled. Until 2017, 3,437 spider species (649 


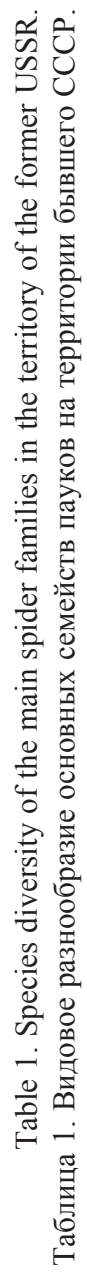

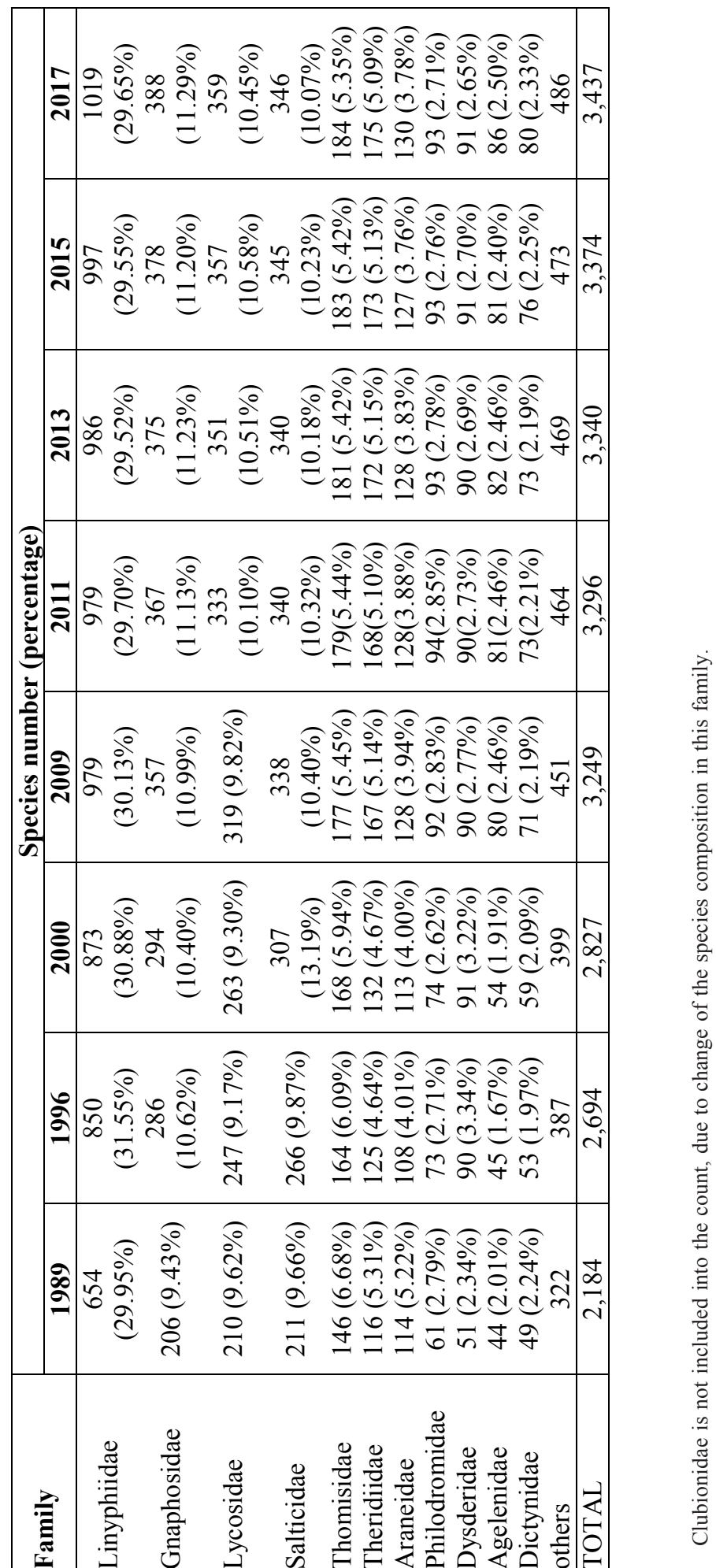


genera) from 53 of the 128 recent families in the world fauna had been reported from the FSU territories (Table 1). Compared to the 2013 checklist, the Clubionidae is split into Clubionidae and Cheiracanthiidae, while the Corinnidae into Corinnidae, Phrurolithidae and Trachelidae. Slight differences in family names and scope as compared to the WSC (2021) are kept in the current checklist. The Argyronetidae is used instead of Cybaeidae, while the Cheracanthiidae is listed separately from Eutichuridae, and the Zoridae is considered separately from the Miturgidae and retains its earlier scope, following Marusik \& Kovblyuk (2011).

A comparison of the species diversity of the FSU (Table 1) shows that the first place in the FSU is taken by Linyphiidae, not Salticidae (as in WSC, 2021). The family Linyphiidae is most diverse in boreal and temporal zones, whereas Salticidae in tropical and subtropical areas; the tropics are totally absent from the FSU, while the subtropics are represented only marginally.

Linyphiidae show the highest diversity in the FSU (Table 1), with over 1,000 species recorded/described. Gnaphosidae, Lycosidae and Salticidae are the next three groups to follow, with their order having changed in 19892013. The second-rich Salticidae in 1989 and 2000 shifted to the third place in 1996, 2009 and 2011. Gnaphosidae were the fourth in 1989 and the third in 2000. Since the 1989 evaluation, the main increase in species numbers has been documented for Linyphiidae (+365 species), followed by Gnaphosidae $(+182)$, Lycosidae $(+149)$, Salticidae $(+135)$ and Theridiidae $(+59)$ (Table 1). Altogether, the increase in species richness was 510 during 1989-1995, or approximately 73 species annually. In 1996-2000, these figures were 130 and 33 , respectively, in 2001-2011, 469 and 43, in 2012-2017, 141 and 23.5. In several families, a great increase in species diversity was reported for 1989-1996: +196 species in Linyphiidae (due to the research of K.Yu. Eskov, A.V. Tanasevitch and Yu.M. Marusik), +80 species in Gnaphosidae (due to Yu.M. Marusik, V.I. Ovtsharenko and D.V. Logunov), +49 species in Dysderidae (due to the late P.M. Dunin). D.V. Logunov is also responsible for a large number of Salticidae records in 1989-2009, +127 species. A second increase in the Linyphiidae number is recorded in 2000-2009 (+106 species, due to A.V. Tanasevitch, Yu.M. Marusik and V.A. Gnelitsa).

An analysis of the spider fauna of the postSoviet countries (Table 2, Supplements 1.011.15) reveals almost the same proportions as earlier: Russia supports the highest diversity (2445 species), followed by Ukraine (1056), Kazakhstan (1010) and Azerbaijan (688). The spider faunas of Moldova and Armenia show no large increase in species numbers, remaining not sufficiently studied yet, apparently due to the absence of local arachnologists. A project devoted to the spider fauna of Armenia started only recently, resolved in 14 additional species recorded between 2015 and 2017. A different situation is observed in Estonia ( +5 species only), one of the best arachnologically studied republics due to the 1960-1980 research by A. Vilbaste. In Lithuania, a lot of species have been added between 2000 and 2011, revealing that its spider fauna is similar to that of Latvia both in a species number and composition; in Latvia, such an increase was found between 2013 and 2015. In 1996-2017, the main increase in species richness was notable in Russia (+571 species), Kazakhstan $(+331)$, Georgia $(+257)$, Ukraine (+248), Lithuania $(+202)$ and Azerbaijan $(+188)$. Most significant contributions to the knowledge of Kazakhstan and Georgian spiders were made by overseas arachnologists. Large increase in the spider fauna of Byelorussia (Belarus) during 2015-2017 (+40) is owed to Zhukovets (2017) book.

No correlation is found between a spider species diversity and an area size (Table 2). In general, larger areas like Russia and Kazakhstan support lesser spider species diversities. Moderate richness levels are reported also in Uzbekistan and Turkmenistan, both dominated by desert landscapes. Mountain areas like Georgia and Azerbaijan are richer in spider species per area unit, yet being comparable in this index with poorly-studied Moldova. 


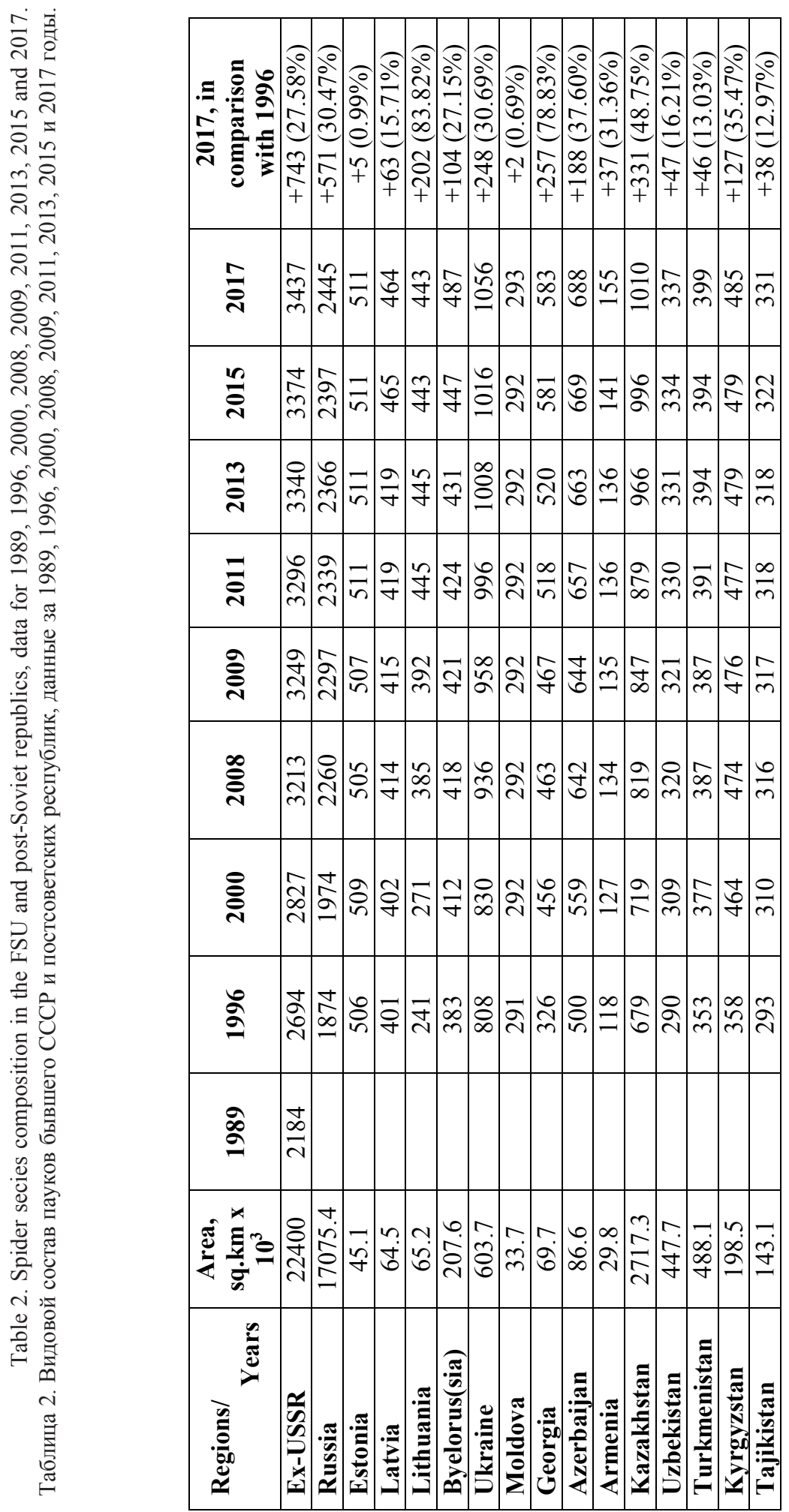


K.G. Mikhailov

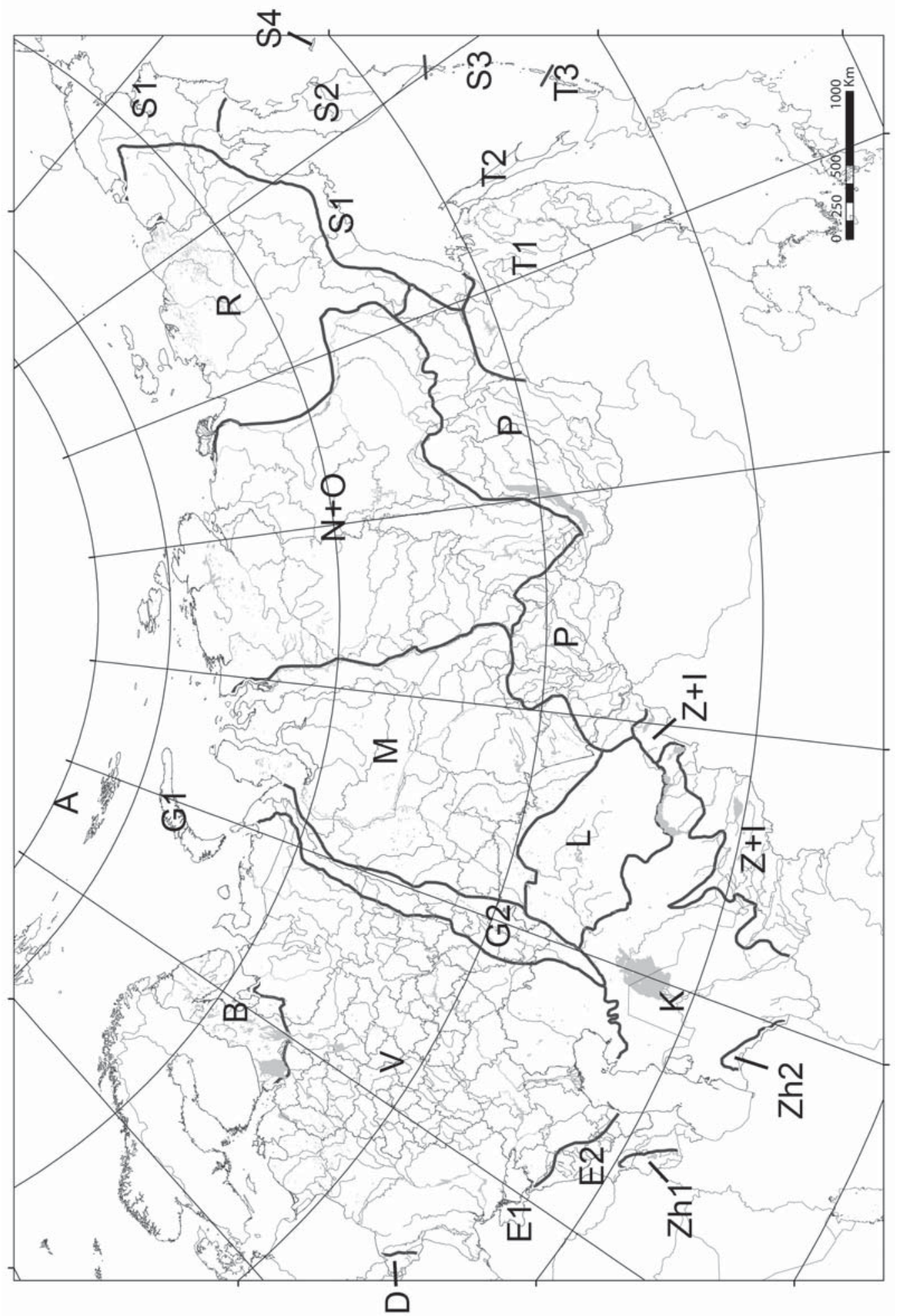


Physiographical regions of the FSU territory are here accepted after Gvozdetsky (1968) (Fig. 1). The main increase during 1996-2017 was observed in the Russian Plain (V, +413 species), the continental southern Far East (T1, +381 species), the Caucasus (E2, +287 species), West Siberia $(\mathrm{M},+283$ species $)$, the Crimea (E1, +250 species), the mountains of South Siberia $(\mathrm{P},+237$ species) (Table 3 , see also species lists in Supplements 2.01-2.24). Moderate increases in Middle Siberia $(\mathrm{N}+\mathrm{O})$, the continental Far North-East (S1) and Sakhalin Island (T2) are explained by earlier (the 1980's to early 1990's for T2) activities both of K.Yu. Eskov and of Yu.M. Marusik. It is noteworthy that in the continental southern Far East (Russia), crucial taxonomic/faunistic studies were largely performed by visiting arachnologists, while in the Crimea by local specialists. Earlier, during 1989-1996, the main progress was made in the mountains of South Siberia $(\mathrm{P},+377$ species, due to D.V. Logunov, Yu. M. Marusik and S.N. Danilov), West Siberia (M, +197 species, due to S.L. Esyunin and others) and northeastern Siberia $(R,+118$ species, the activities of Yu.M. Marusik).

The data provided herein are difficult to compare with the adjacent regions such as West and Central Europe, China or Japan. The recent country calculations are available for Europe (Helsdingen, 2020), also with data on European Russia and Ukraine. For example, Poland, which is $312.710^{3} \mathrm{~km}^{2}$ in area, supports 844 spider species. This is comparable with 1056 species in Ukraine and 1016 in Germany (357.4 10 3 $\left.\mathrm{km}^{2}\right) .642$ species in Finland $\left(33810^{3} \mathrm{~km}^{2}\right)$ correspond to 589 species in Fennoscandia. A total of 2361 spider species were registered in the whole territory of China earlier (Song et al., 1999); 3714 species in 2013 (Shuqiang Li, pers. comm.), 4282 species (Li, Lin, 2016) and currently 5084 species (Li, 2020). To date, 1647 species and subspecies are known from Japan (Shinkai et al., 2020) in comparison with 1574 species in 2013 (A. Tanikawa, pers. comm., 2013).

Earlier estimates of the total FSU spider fauna first amounted to 2700-3000 species (Mikhailov, 1992), later to 3400-3500 species (Mikhailov, 1997). The latest prediction, with the total spider diversity of the FSU being likely to be 3700-3800 species, and that of Russia 2500-2600 species (Mikhailov, 2013a), seems to be worth updating to 4000 and 2700-2800 species correspondingly. Faunistic studies of the spiders of Russia and the FSU are yet far from complete.

Fig. 1. Physiographical regions of the FSU after Gvozdetsky (1968): A - Atlantic-Arctic area, B Fennoscandia, V - Russian Plain, G1 - Novaya Zemlya, G2 — Urals, D - Carpathians, E1 — Crimea, E2 - Caucasus, Zh1 - Armenian Upland, Zh2 - Kopet Dagh Mts, Z+I - mountains of Middle (= Central) Asia, K - deserts of Middle (= Central) Asia, L — Kazakhstan hills, M — West Siberia, N+O — Middle Siberia, P — mountains of South Siberia, R - Northeastern Siberia, S1 — continental Far North-East, S2 — Kamchatka, S3 - N-Kuriles, S4 — Commander Islands, T1 — continental southern Far East, T2 Sakhalin, T3 — S-Kuriles. English capital letters correspond to the Russian ones given in Gvozdetsky's book.

Рис. 1. Физико-географические регионы бывшего СССР по Н.А. Гвоздецкому (Gvozdetsky, 1968): А Атлантико-Арктическая область, В - Фенноскандия, V - Русская равнина, G1 - Новая Земля, G2 - Урал, D - Карпаты, E1 - Крым, E2 - Кавказ, Zh1 - Армянское нагорье, Zh2 - Копет-Даг, Z+I - горы Средней (Центральной) Азии, K — пустыни Средней (Центральной) Азии, L Казахстанский мелкосопочник, $\mathrm{M}$ - Западная Сибирь, $\mathrm{N}+\mathrm{O}$ - Средняя Сибирь, P - горы Южной Сибири, R - Северо-восточная Сибирь, S1 - континентальный Дальний Северо-Восток, S2 Камчатка, S3 - Северный Курилы, S4 - Командорские о-ва, T1 - континентальный южный Дальний Восток, Т2 - Сахалин, Т3 - Южные Курилы. В книге Н.А. Гвоздецкого приведены русские буквенные обозначения, которые здесь даны в транслитерации. 


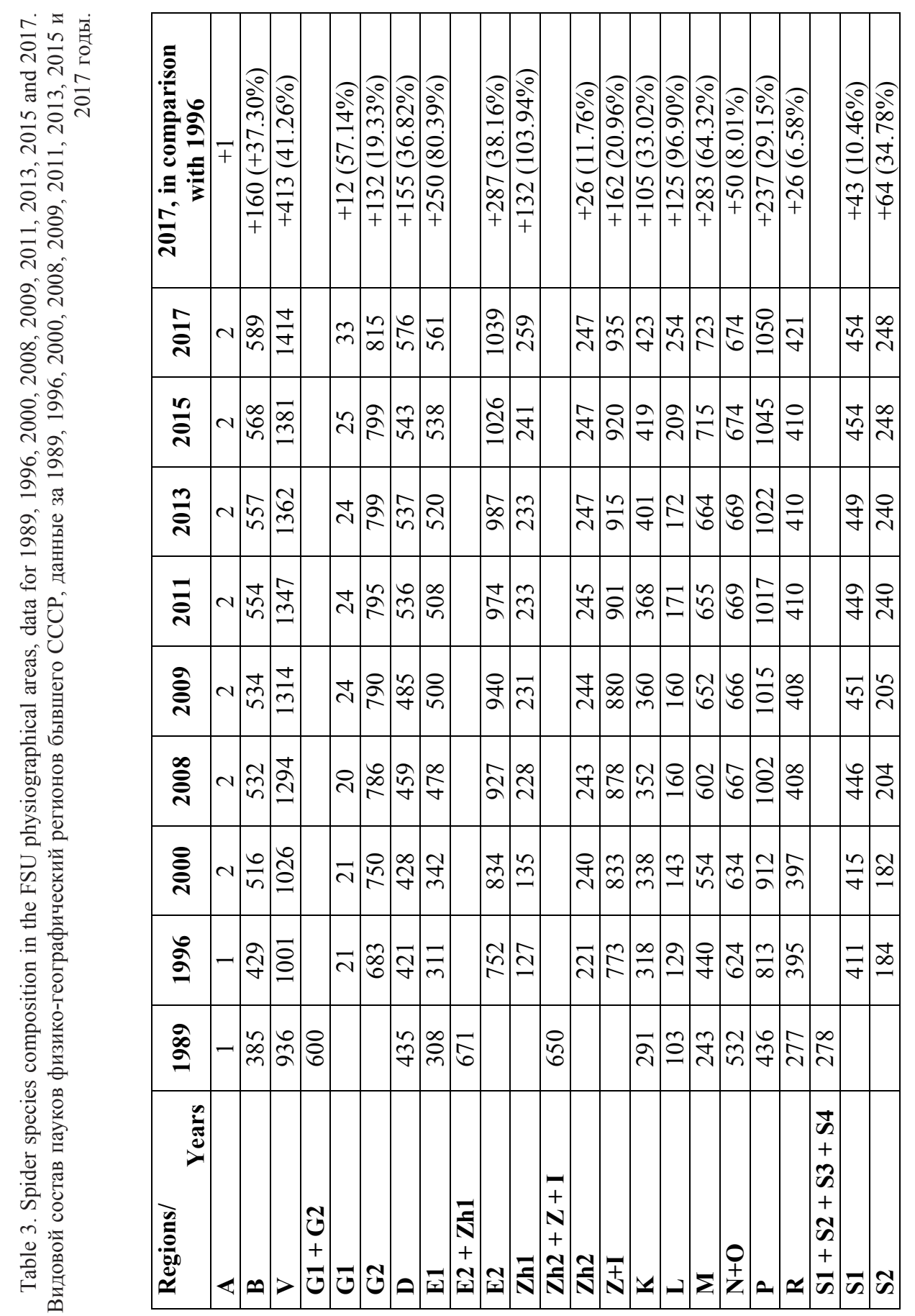




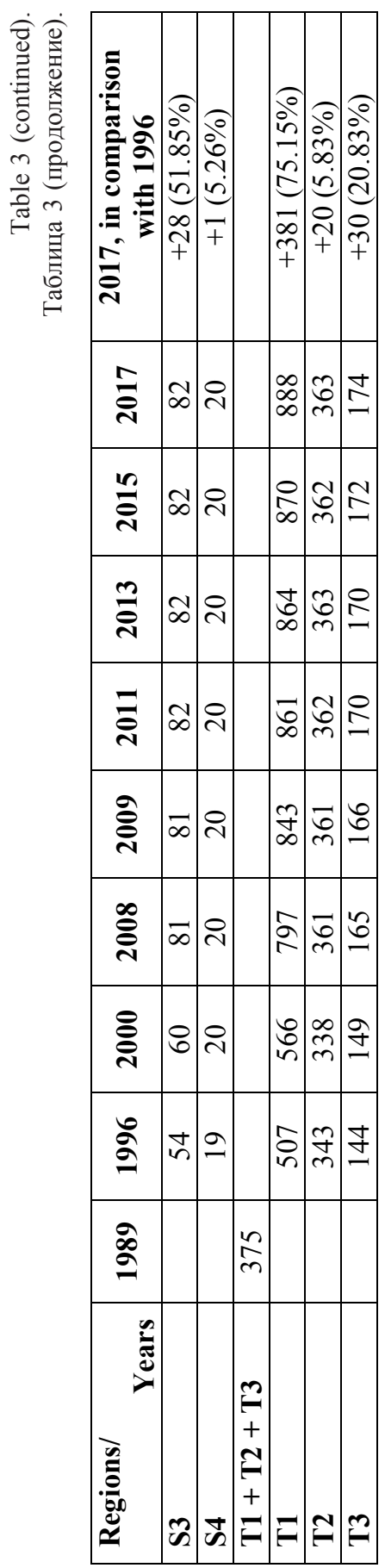

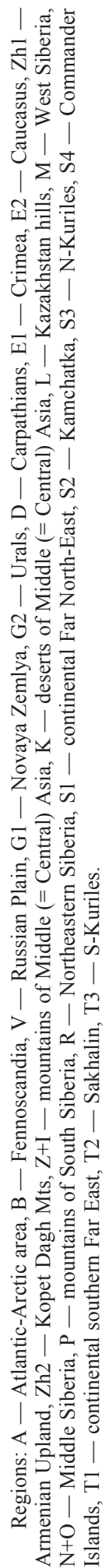

Supplementary data. The following Excel-tables are available online.

Supplement 1. Lists of spiders of Russia and FSU republics.

1.01. Russia.

1.02. Estonia.

1.03. Latvia.

1.04. Lithuania.

1.05. Byelorussia (Belarus).

1.06. Ukraine.

1.07. Moldavia (Moldova).

1.08. Georgia.

1.09. Azerbaijan.

1.10. Armenia.

1.11. Kazakhstan.

1.12. Uzbekistan.

1.13. Turkmenistan.

1.14. Kirghizia (Kyrghyzstan).

1.15. Tadzhikistan.

Supplement 2. Lists of spiders of FSU physiographical regions.

2.01. Atlantic-Arctic area (A).

2.02. Fennoscandia (B).

2.03. Russian Plain (V).

2.04. Novaya Zemlya (G1).

2.05. Urals (G2).

2.06. Carpathians (D).

2.07. Crimea (E1).

2.08. Caucasus (E2).

2.09. Armenian Upland (Zh1).

2.10. Kopet Dagh Mts (Zh2).

2.11. Mountains of Middle (= Central) Asia $(\mathrm{Z}+\mathrm{I})$.

2.12. Deserts of Middle (= Central) Asia (K).

2.13. Kazakhstan hills (L).

2.14. West Siberia (M).

2.15. Middle Siberia $(\mathrm{N}+\mathrm{O})$.

2.16. Mountains of South Siberia (P).

2.17. Northeastern Siberia (R).

2.18. Continental Far North-East (S1).

2.19. Kamchatka (S2).

2.20. N-Kuriles (S3).

2.21. Commander Islands (S4).

2.22. Continental southern Far East (T1).

2.23. Sakhalin (T2).

2.24. S-Kuriles (T3). 
Acknowledgements. I am most grateful to Dr Yuri M. Marusik (Magadan, Russia) for his comprehensive critiques and useful suggestions for previous version of this paper and Dr Dmitry V. Logunov (Manchester, Great Britain) for both linguistic and logistic help. The work is supported by MSU Zoological Museum State Program.

\section{References}

Bonnet P. 1955. Bibliographia araneorum. Toulouse: Les Artisants de 1'Imprimerie Douladoure. Vol.2 (1 $1^{\text {re }}$ partie: A-B). P.1-918.

Bonnet P. 1956. Bibliographia araneorum. Toulouse: Les Artisants de 1'Imprimerie Douladoure. Vol.2 (2 $2^{\mathrm{me}}$ partie: C-F). P.919-1926.

Bonnet P. 1957. Bibliographia araneorum. Toulouse: Les Artisants de 1'Imprimerie Douladoure. Vol.2 ( $3^{\mathrm{me}}$ partie: G-M). P.1927-3026.

Bonnet P. 1958. Bibliographia araneorum. Toulouse: Les Artisants de 1'Imprimerie Douladoure. Vol.2 (4 ${ }^{\mathrm{me}}$ partie: N-S). P.3027-4230.

Bonnet P. 1959. Bibliographia araneorum. Toulouse: Les Artisants de 1'Imprimerie Douladoure. Vol.2 (5 $5^{\mathrm{me}}$ partie: T-Z). P.4231-5058.

Charitonov D.E. 1932. [Katalog der russischen Spinnen]. Leningrad: AN SSSR Publ. 206 p. [In Russian and German]

Eskov K.Yu. 1994. Catalogue of the linyphiid spiders of northern Asia (Arachnida, Araneae, Linyphiidae). Sofia-Moscow: PENSOFT Publ. 144 p.

Esyunin S.L., Efimik V.E. 1996. Catalogue of the spiders (Arachnida, Aranei) of the Urals. Moscow: KMK Scientific Press Ltd. 229 p.

Gvozdetsky N.A. 1968. [Physiographical regioning of the USSR]. Moscow: MGU Publishers. 576 p., 1 map [In Russian]

Helsdingen P.J., van. 2020. Araneae. Fauna Europaea. Database. European Spiders and their distribution. Distribution. Version 2020.2. Available via http:// www.european-arachnology.org/wdp/?page_id=59, accessed on January 8th, 2021

Kharitonov D.E. 1936. [An addition to the catalogue of Russian spiders] // Uchenye zapiski Permskogo universiteta. Vol.2. No.1. P.167-225 [In Russian, with German summary].

Kovblyuk N.M., Kastrygina Z.A. 2015. [Updated catalogue of the spiders (Arachnida, Aranei) of the Crimea] // Ukrainska Entomofaunistyka. Vol.6. No.2. P.1-81 [in Russian, with Ukrainian and English summaries].

Krasnobaev Yu.P. 2004. [Catalogue of the spiders (Aranei) of the Middle Povolzhye]. Samara: Zhiguli State Nature Reserve. 213 p. [in Russian]

Li Shuqiang. 2020. Spider taxonomy for an advanced China // Zoological Systematics. Vol.45. No.2. P.7377.
Li Shuqiang, Lin Yucheng. 2016. Species cataloque of China. Volume 2. Animalia. Invertebrates (I). Arachnida: Araneae. Beijing: Science Press. 567 p. [In Chinese]

Logunov D.V., Marusik Yu.M. 2000a. Catalogue of the jumping spiders of northern Asia (Arachnida, Araneae, Salticidae). Moscow: KMK Sci. Press Ltd. 299 p.

Logunov D.V., Marusik Yu.M. 2003. A revision of the genus Yllenus Simon, 1868 (Arachnida, Araneae, Salticidae). Moscow: KMK Sci. Press Ltd. 167 p.

Marusik Yu.M., Kovblyuk M.M. 2011. [Spiders of Siberia and the Far East of Russia]. Moscow: KMK Scientific Press. 344 p. [In Russian, with English summary]

Marusik Yu.M., Logunov D.V., Koponen S. 2000. Spiders of Tuva, South Siberia. Magadan: IBPN FEB RAS. $252 \mathrm{p}$.

Mikhailov K.G. 1987. Contribution to the spider fauna of the genus Micaria Westring, 1851 of the USSR. I (Aranei, Gnaphosidae)// Spixiana. Bd.10. H.3. P.319334.

Mikhailov K.G. 1992a. [Results of the study of the USSR spider fauna] // V.I. Ovtsharenko (ed.). Fauna i ekologiya paukov, skorpionov i lozhnoskorpionov SSSR. Trudy Zoologicheskogo instituta AN SSSR. Leningrad. Vol.226. P.127-129 [in Russian].

Mikhailov K.G. 1992b. The spider genus Clubiona Latreille, 1804 (Arachnida Aranei Clubionidae) in the USSR fauna: a critical review with taxonomical remarks // Arthropoda Selecta. Vol.1. No.3. P.3-34.

Mikhailov K.G. 1997. Catalogue of the spiders of the territories of the former Soviet Union (Arachnida, Aranei) // Sbornik trudov Zoologicheskogo muzeya MGU. Moscow. Vol.37. 416 p.

Mikhailov K.G. 2002. The spider fauna of Russia and other post-Soviet republics: a 2000 update // S. Toft, N. Scharff (eds.). European Arachnology 2000. Proceedings of the $19^{\text {th }}$ European Colloquium on Arachnology. Åarhus. P.255-259.

Mikhailov K.G. 2003. The spider genus Clubiona Latreille, 1804 (Aranei, Clubionidae) in the fauna of the former USSR: 2003 update // Arthropoda Selecta. Vol.11 (for 2002). No.4. P.283-317.

Mikhailov K.G. 2012a. [Bibliographia Araneologica Rossica 1770-2011] // Trudy Russkogo entomologicheskogo obshchestva. St. Petersburg. Vol.83. No.2. P.1-229 [in Russian, with English summary].

Mikhailov K.G. 2012b. The spider fauna of Russia and adjacent regions: a 2009 update // Russian Entomol. J. Vol.21. No.2. P.165-168.

Mikhailov K.G. 2013a. Advances in the study of the spider (Aranei) fauna of Russia and adjacent regions: a 2011 update // Arthropoda Selecta. Vol.22. No.1. P.47-53.

Mikhailov K.G. 2013b. The spiders (Arachnida: Aranei) of Russia and adjacent countries: a non-annotated checklist // Arthropoda Selecta. Suppl. No.3. 262 p.

Mikhailov K.G. 2016. Advances in the study of the spider fauna (Aranei) of Russia and adjacent regions: a 2015 update//Vestnik zoologii. Vol.50. No.4. P.309320 . 
Mikhailov K.G. 2019. Bibliographia Araneologica Rossica (Bibliography on spiders of Russia and post-USSR republics). Addendum 1. 2012-2015. Moscow: KMK Scientific Press. 69 p. [In Russian]

Mikhailov K., Fet V. 1994. Fauna and zoogeography of spiders (Aranei) of Turkmenistan // V. Fet, K. Atamuradov (eds.). Biogeography and ecology of Turkmenistan. Monogr. Biol. Vol.72. Dordrecht etc.: Kluwer Academic Publ. P.499-524.

Mkheidze T.S. 1997. [Spiders of Georgia (systematics, ecology, zoogeographical review)] Tbilisi: Tbilisi State Univ. Press. 390 p. [In Georgian, with Russian summary]

Platnick N.I. 2014. The World Spider Catalog. Version 15. American Museum of Natural History. Available via http://research.amnh.org/iz/spiders/catalog_15.0/ index.html, accessed on January 07th, 2021

Polchaninova N.Yu., Prokopenko E.V. 2013. Catalogue of the spiders (Arachnida, Aranei) of Left-Bank Ukraine // Arthropoda Selecta. Suppl. No.2. 268 p.

Polchaninova N.Yu., Prokopenko E.V. 2017. Catalogue of the spiders (Arachnida, Aranei) of Left-Bank Ukraine. Addendum 1. 2013-2016 // Arthropoda Selecta. Suppl. No.4. 115 p.

Roewer C.F. 1942. Katalog der Araneae von 1758 bis 1940. Bremen. Bd.1 (Mesothelae, Orthognatha, Labidognatha: Dysderaeformia, Scytodiformia, Pholci- formia, Zodariiformia, Hersiliaeformia, Argyopiformia). S.1-1040.

Roewer C.F. 1954a. Katalog der Araneae von 1758 bis 1940, bzw. 1954. Bruxelles: Institut royal des Sciences naturelles de Belgique. Bd.2. Abt.a (Lycosaeformia, Dionycha [excl. Salticiformia]). S.1-923.

Roewer C.F. 1954b. Katalog der Araneae von 1758 bis 1940, bzw. 1954. Bruxelles: Institut royal des Sciences naturelles de Belgique. Bd.2. Abt.b (Salticiformia, Cribellata) (Synonyma-Verzeichnis, Gesamtindex). S.925-1751.

Shinkai A., Andoh A., Tanikawa A., Ikeda H., Kuwata T. 2020. CD Japanese Spiders, ver.2020. Self-published by the authors.

Song Daxiang., Zhu Minsheng, Chen Jun. 1999. The spiders of China. Shijiazhuang: Hebei Science and Technology Publishing House. 640 p., 4 pl.

Vilbaste A. 1987. Eesti ämblikud (Aranei) Annoteeritud nimestik [Estonian spiders. An annotated checklist]. Tallinn: Valgus. 178 lk. [In Estonian, with Russian and English abstracts]

WSC. 2021. World Spider Catalog. Version 21.5. Natural History Museum Bern. Online at http://wsc.nmbe.ch, accessed on 06.01.2021

Zhukovets E.M. 2017. [Spiders (Arachnida, Aranei)of Byelovezhskaya Pushcha.] Minsk: RIFTUR PRINT. 269 p. [In Russian]

Responsible editor E.N. Temereva 